\title{
PERANCANGAN MESIN PENGUPAS KEDELAI DENGAN METODE WET PROCESS SKALA HOME INDUSTRY
}

\author{
Peniel I. Gultom ${ }^{1)}$, Priscilla Tamara ${ }^{2)}$ \\ 1) Prodi Teknik Mesin DIII, Fakultas Teknologi Industri, Institut Teknologi Nasional Malang \\ ${ }^{1)}$ Prodi Teknik Industri DIII, Fakultas Teknologi Industri, Institut Teknologi Nasional Malang \\ Email : peniel_immanuel@yahoo.com
}

\begin{abstract}
Abstrak, Kedelai adalah sumber protein nabati yang sangat baik. Berbagai jenis makanan menggunakan kedelai sebagai bahan bakunya. Salah satunya dalam pembuatan tempe, makanan khas Indonesia yang dapat dibuat menjadi berbagai jenis penganan, misalnya cake tempe, lauk pauk, dan keripik. Kota Malang adalah salah satu daerah industri kecil penghasil penganan dari tempe khususnya keripik tempe. Sentra industri kecil keripik tempe yang terkenal, yaitu Kampung Tempe Sanan yang terletak di Kelurahan Purwantoro. Adapun kesulitan yang dihadapi oleh home industry keripik tempe ini adalah dalam proses produksinya masih manual. Salah satunya dalam proses pengupasan kedelai yang menggunakan tenaga manusia, yaitu dengan cara diinjak-injak. Tentunya hal ini mempengaruhi higienitas kedelai dan produktifitas kerja. Penelitian ini akan membuat rancang bangun mesin pengupas kedelai berkapasitas relatif kecil yang disesuaikan untuk skala home industry (UKM). Mesin ini dirancang untuk mengupas kedelai dengan menggunakan metode wet process (proses basah). Hasil rancang bangun menunjukkan mesin berkapasitas $15 \mathrm{~kg}$ ini dapat mengupas kedelai dalam waktu 28,86 menit atau 31,2 $\mathrm{kg} / \mathrm{jam}$.
\end{abstract}

Kata kunci : kedelai, rancang bangun, wet process

\section{PENDAHULUAN}

Kedelai adalah sumber protein yang baik dan digunakan sebagai bahan makanan nabati, misalnya tepung, minyak dan susu. Bermanfaat juga sebagai pakan ternak, bahan cat, kosmetik, dan sabun (Etiosa dkk, 2017). Biji kacang kedelai merupakan bagian terpenting, yang mana hingga limbahnya pun mempunyai manfaat sebagai tambahan pakan ternak yang bergizi hingga sebagai bahan tambahan dalam pembuatan particelboard (Martins dkk, 2017).

Sebelum kedelai diproses untuk menjadi berbagai bahan makanan dan bahan industri, terlebih dulu dilakukan pengupasan kulit ari pada biji kedelai. Kulit ari ini nantinya juga dapat dimanfaatkan sebagai bahan tambahan pada pakan broiler (Harahap dkk, 2020). Pengupasan biji kedelai yang bersih dan baik akan menghasilkan kedelai yang berkualitas bagus untuk proses pengolahan selanjutnya, misalnya untuk pembuatan tempe dan tahu (Setiono dkk, 2018). Namun masih banyak ditemukan proses pengupasan biji kedelai secara manual atau menggunakan tenaga manusia, terutama pada industri rumah tangga di pedesaan. Proses pemecahan biji kedelai manual hasilnya kurang memuaskan karena selain kurang bersih akibat masih ada kulit yang tersisa, kurang higienis karena prosesnya dengan cara diinjak-injak, juga menghabiskan tenaga dan waktu lama.

Mesin pengupas kacang kedelai yang ada di pasaran kebanyakan diperuntukkan bagi industri besar dan menengah, akibatnya sulit terjangkau bagi pengusaha kecil oleh karena relatif mahal dan berkapasitas besar. Selain itu dimensi yang besar juga menyulitkan tata letak mesin di industri kecil.

Penelitian ini khususnya akan ditekankan pada pengupasan kulit ari kacang kedelai, oleh karena proses ini adalah proses paling sulit untuk mendapatkan hasil yang banyak. Permasalahannya adalah bagaimana mendesain mesin pengupas kedelai akan meningkatkan kualitas dan kuantitas hasil pengupasan. Kapasitas mesin ditentukan untuk $15 \mathrm{~kg}$ kedelai dalam sekali proses berdasarkan jumlah kedelai yang dikupas secara manual saat ini. Waktu pengupasan yang diharapkan adalah 24 menit untuk $15 \mathrm{~kg}$ kedelai. Luaran yang diperoleh merupakan sebuah prototype mesin pengupas kedelai dengan metode wet process yang kapasitasnya disesuaikan untuk home industry.

Rozikin dan Umar (2018), dalam penelitiannya yang berjudul "Rancang Bangun Mesin Pengupas Kulit Ari Kedelai Dengan Kapasitas 180kg/Jam Untuk Industri Tempe" menyatakan bahwa rancang bangun mesin ini sederhana, menggunakan motor untuk 
menggerakkan belt dengan daya kecil dan pengupasnya menggunakan gerinda. Mesin ini mampu mengupas dan memecah kulit ari kedelai dengan kapasitas $180 \mathrm{~kg} / \mathrm{jam}$. Putaran mesin 410,3 rpm, daya $1 / 4$ pk dan gaya gesek 5,90 newton, koefisien gesek 1,2.

Suhendra dan Setiawan (2012) menyatakan bahwa mesin pengupas kulit ari dan pembelah biji kedelai yang ada di pasaran tingkat efisiensinya masih rendah dan perlu perbaikan. Penelitian yang dilakukan menggunakan program Powersim untuk membuat mesin pengupas dan pembelah biji kedelai tipe piringan. Hasil simulasi menunjukkan bahwa efisiensi kedelai terkupas dan terbelah tertinggi mencapai $100 \%$ pada ukuran celah 4,8 mm, dengan kapasitas 48,02 $\mathrm{kg} / \mathrm{jam}$ dan membutuhkan gaya kupas kondisi sebesar 287,83 Newton.

\section{METODE}

Dalam rancang bangun mesin ini terdapat tahapan proses dengan alur seperti di bawah ini :

1. Survei di lokasi, untuk pencatatan cara kerja pengupasan kulit ari kedelai secara manual dan dengan mesin yang ada di pasaran untuk dasar pemikiran dalam proses rekayasa.

2. Penelusuran kepustakaan, yang bertujuan untuk tujuannya adalah untuk menemukan kesenjangan penelitian dari hasil yag telah ada sebelumnya. Kepustakaan ini bisa dalam bentuk buku dan jurnal terbaru.

3. Membuat perumusan masalah yang mana dilanjutkan batasan masalah agar penelitian ini dapat fokus pada tujuan yang akan dicapai. Penentuan perhitungan awal waktu kerja dan jumlah produksi pada proses tanpa alat (manual).

4. Mendesain mesin, dalam mencari solusi optimal sesuai dengan permasalahan.

5. Membuat purwarupa sesuai dengan desain terpilih sebagai wujud solusi yang ditawarkan.

6. Setelah purwarupa jadi maka dilakukan evaluasi, dengan implementasi mesin di UKM dengan menggunakan bahan baku yang tersedia di UKM tersebut. Jika tertemukan hal-hal yang belum sesuai dalam pengoperasian. Apabila ditemukan mesin maka akan segera diperbaiki agar dapat sesuai dengan spesifikasi yang telah ditentukan. Perhitungan kembali waktu kerja dan jumlah produksi dengan menggunakan mesin.
7. Akhir dari penelitian ini tertuang dalam kesimpulan dan akan diberikan rekomendasi sebagai bentuk catatan demi mendapatkan hasil yang optimal.

Adapun alur penelitian dapat dilihat pada gambar 1 di bawah ini :

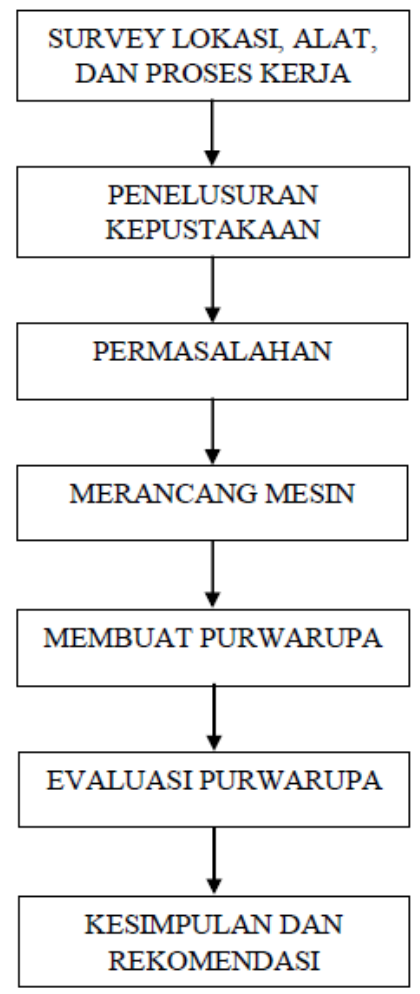

Gambar 1. Tahapan proses penelitian

\section{HASIL DAN PEMBAHASAN}

\section{Proses Pengolahan Kedelai}

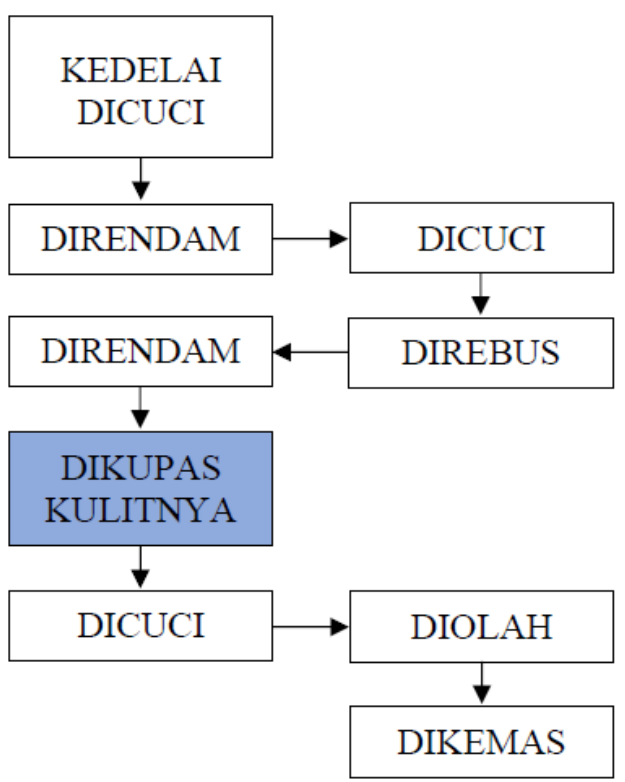

Gambar 2. Proses pengolahan kedelai 
2. Proses Pengupasan Kedelai Secara Manual

Dalam proses pengupasan kulit kedelai tanpa bantuan alat (manual) ada beberapa tahap yang dilakukan, yaitu sebagai berikut:

- Kedelai yang sudah direbus, dicuci dahulu atau setelah dingin bisa langsung dimasukkan ke dalam ember kemudian diberi air.

- Kedelai diinjak-injak dalam ember untuk melepaskan kulitnya. Proses menginjak ini biasanya dilakukan 2 kali agar bersih.

- Kulit disaring kemudian dibuang.

- Kedelai siap diolah.

\section{Waktu Kerja Pengupasan Kedelai Cara} Manual

- Kebutuhan pengupasan kedelai dalam satu kali proses, yaitu $15 \mathrm{~kg}$ dalam sekali proses pengupasan.

- Waktu normal proses pengupasan kedelai tanpa alat. Perhitungan berdasarkan faktor kelonggaran yang sudah ditetapkan (Tarigan, 2015). Adapun waktu rata-rata $=29,82$ menit, yaitu :

$$
\begin{aligned}
W n & =W_{s} \times P \\
& =29,82 \times 1,12 \\
& =33,39 \text { menit } / 15 \mathrm{~kg}
\end{aligned}
$$

- Penetapan prosentase kelonggaran (Fitra, 2020) :

- Kebutuhan pribadi $\quad=2 \%$

- Penyesuaian kelelahan

- Tenaga yang dikeluarkan $=4 \%$

- Sikap kerja $\quad=2 \%$

- Kelelahan kerja $\quad=3 \%$

- Keadaan tempat kerja $=3 \%$

- Hambatan-hambatan $=1 \%$

Total $\quad=15 \%$

- Perhitungan waktu standar (Rahman, 2013)

$$
\begin{aligned}
W s & =W n \times \frac{100 \%}{100 \%-\operatorname{all}(\%)} \\
& =33,39 \times \frac{100 \%}{100 \%-15 \%} \\
& =39,28 \text { menit } / 15 \mathrm{~kg}(1 \mathrm{x} \text { injak }) \\
& =78,56 \text { menit } / 15 \mathrm{~kg}(2 \mathrm{x} \text { injak }) \\
& =2,62 \text { menit } / \mathrm{kg}
\end{aligned}
$$

- Output standar:

$$
O s=\frac{1}{\mathrm{~Wb}}
$$

$$
\begin{aligned}
& =\frac{1}{2,62} \\
& =0,38 \mathrm{~kg} / \text { menit } \\
& =22,8 \mathrm{~kg} / \mathrm{jam}
\end{aligned}
$$

\section{Antropometri}

Tabel 1. Hasil Perhitungan Antropometri

\begin{tabular}{|l|c|c|c|}
\hline \multicolumn{1}{|c|}{ Pengukuran } & $\mathbf{5 \%}$ & $\mathbf{5 0 \%}$ & $\mathbf{9 5 \%}$ \\
\hline $\begin{array}{l}\text { Tinggi Mata Posisi } \\
\text { Berdiri }\end{array}$ & 142.24 & 150.9 & 161.95 \\
\hline $\begin{array}{l}\text { Tinggi Siku Posisi } \\
\text { Berdiri }\end{array}$ & 103.23 & 107.1 & 113.5 \\
\hline Tinggi Mata Duduk & 67 & 71.55 & 74.43 \\
\hline Tinggi Siku Duduk & 22 & 26.05 & 30.25 \\
\hline $\begin{array}{l}\text { Panjang Jangkauan } \\
\text { Ke Samping }\end{array}$ & 81.4 & 86.15 & 90.0 \\
\hline $\begin{array}{l}\text { Panjang Jangkauan } \\
\text { Ke Depan }\end{array}$ & 71.9 & 78.13 & 83.1 \\
\hline
\end{tabular}

\section{Desain Mesin Pengupas Kedelai}

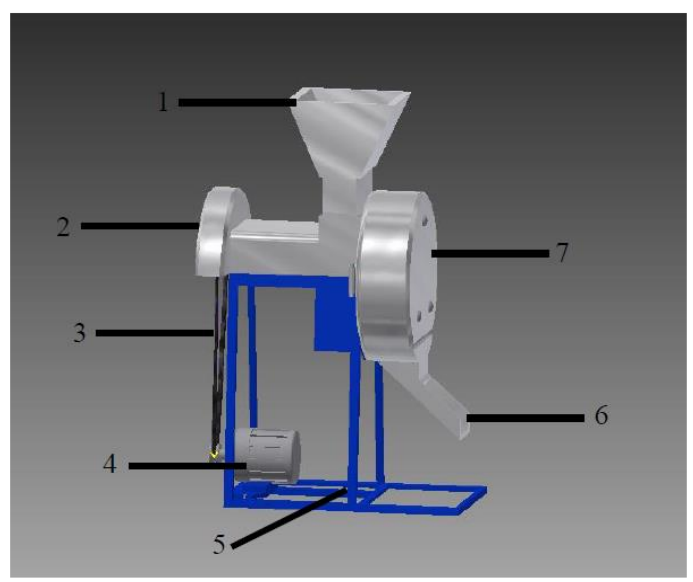

Gambar 3. Rancangan mesin pengupas kedelai

Keterangan :

1. Corong masuk

2. Puli

3. Sabuk (belt)

4. Motor listrik

5. Rangka

6. Corong keluar

7. Penutup batu pengupas 


\section{Hasil Rancangan}

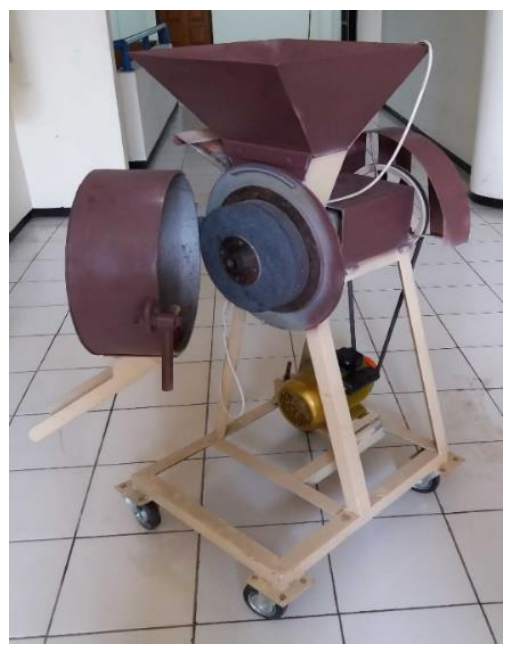

Gambar 4. Mesin Pengupas Kedelai

\section{Evaluasi}

Setelah purwarupa terwujud, langkah selanjutnya adalah evaluasi mesin dengan menggunakannya di UKM yang bersangkutan, dengan bahan baku kedelai yang tersedia di UKM. Dengan demikian dapat dilihat apakah proses pengupasan kedelai dengan menggunakan mesin tersebut berjalan sesuai ketentuan dalam perancangan.

Hasil evaluasi mesin pengupas kacang kedelai ini seperti yang tampak pada gambar 5 dan gambar 6.

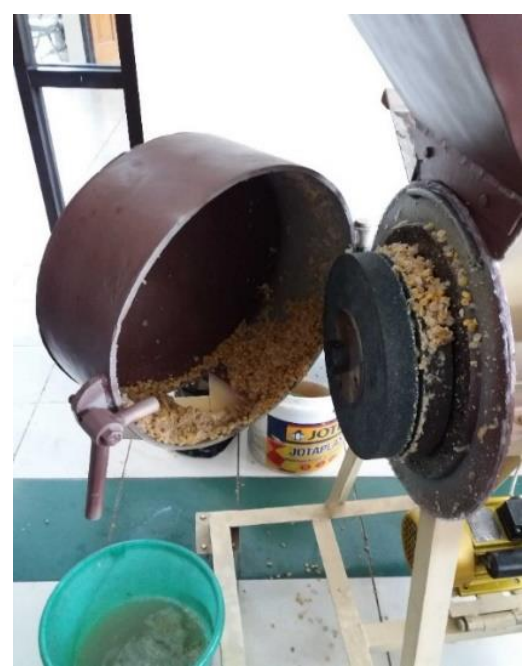

Gambar 5. Pembukaan penutup batu pengupas

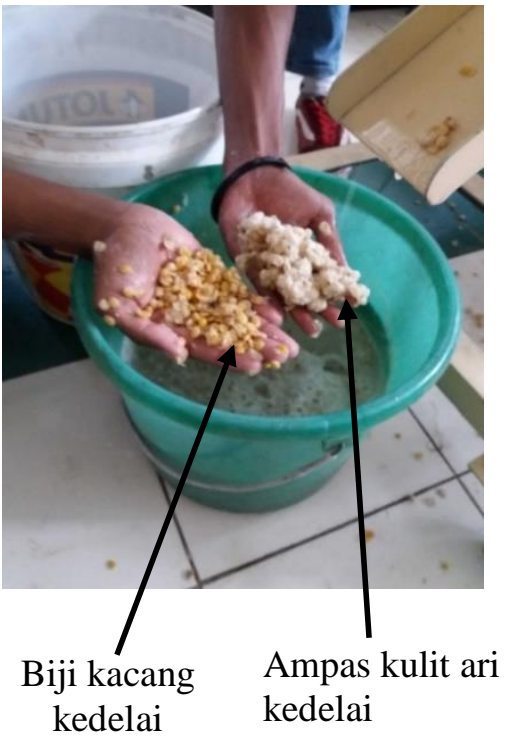

Gambar 6. Hasil pengupasan kedelai

8. Waktu Kerja Pengupasan Dengan Mesin

- Kebutuhan pengupasan kedelai dalam satu kali proses $15 \mathrm{~kg}$.

- Waktu normal proses pengupasan kedelai tanpa alat. Perhitungan berdasarkan faktor kelonggaran yang sudah ditetapkan (Tarigan, 2015). Adapun waktu rata-rata $=23,2$ menit, yaitu :

$$
\begin{aligned}
W n & =W_{s} \times P \\
& =23,2 \times 1,12 \\
& =25,98 \mathrm{mnt} / 15 \mathrm{~kg}
\end{aligned}
$$

- Penetapan prosentase kelonggaran (Fitra, 2020) :

- Kebutuhan pribadi $\quad=2 \%$

- Penyesuaian kelelahan

- Tenaga yang dikeluarkan $=3 \%$

- Sikap kerja $\quad=2 \%$

- Kelelahan kerja $\quad=2 \%$

$\begin{aligned} \text { - } \text { Hambatan-hambatan } & =1 \% \\ \text { Total } & =10 \%\end{aligned}$

- Perhitungan waktu standar (Rahman, 2013)

$$
\begin{aligned}
W s & =W n \times \frac{100 \%}{100 \%-\operatorname{all}(\%)} \\
& =25.98 \times \frac{100 \%}{100 \%-10 \%} \\
& =28,86 \text { menit } / 15 \mathrm{~kg} \\
& =1,92 \text { menit } / \mathrm{kg}
\end{aligned}
$$


- Output standar :

$$
\begin{aligned}
O s & =\frac{1}{\mathrm{~Wb}} \\
& =\frac{1}{1,92} \\
& =0,52 \mathrm{~kg} / \mathrm{menit} \\
& =31,2 \mathrm{~kg} / \mathrm{jam}
\end{aligned}
$$

\section{KESIMPULAN DAN SARAN Kesimpulan}

Dari analisis dan pembahasan yang telah dilakukan dapat ditarik kesimpulan hal-hal yang berkaitan dengan rancang bangun pada mesin pengupas kacang kedelai dengan metode wet process untuk skala home industry sebagai berikut :

a) Penggunaan mesin pengupas kedelai ini menghasilkan efisiensi, kenyamanan dan kemudahan proses kerja pengupasan kedelai yang sebelumnya tanpa alat (manual), oleh karena dengan penggunaan mesin ini proses pengupasan kedelai tidak dilakukan dengan cara diinjak-injak melainkan menggunakan mesin.

b) Dimensi mesin sesuai ukuran tubuh operator.

c) Terjadi peningkatan produktifitas kerja setelah menggunakan mesin pengupas kedelai ini dibanding dengan pengupasan tanpa alat (manual).

d) Pengupasan kedelai menjadi lebih bersih, higienis, dan manusiawi karena sudah memakai mesin dan tidak diinjak-injak lagi.

e) Ouput yang diperoleh adalah sebesar 31,2 $\mathrm{kg} / \mathrm{jam}$ (terjadi kenaikan sebesar $104 \%$ ) dan dalam waktu 28,86 menit (terjadi pengurangan waktu sebesar 47 menit / 306 $\%)$

\section{Saran}

Mesin pengupas kedelai ini secara implementasi dapat meningkatkan produktifitas kerja dan mempersingkat waktu kerja pengupasan kedelai. Akan tetapi tentunya dapat dikembangkan dan diperkaya lagi dengan penelitian lanjutan yang membahas dari segi lainnya, misalnya penggunaan sistem sirkulasi air. Dengan demikian mesin pengupas kedelai ini akan lebih optimal lagi dalam membantu UKM untuk peningkatan usahanya.

\section{DAFTAR PUSTAKA}

Etiosa, O. R., Chika, N. B., and Benedista, A. 2017. Mineral and Proximate Composition of Soya Bean, Asian Journal of Physical and Chemical Sciences, Vol. 4, No. 3, pp. 1-6.

Fitra. 2020. Perhitungan Waktu Standar Pelayanan Kasir Minimarket X Di Kota Dumai, UNITEK, Jurnal Universal Teknologi, Vol. 13, No. 2, pp. 11-17.

Harahap, A. E., Hidayati, Sri Devi, Solfan, Bakhendri. 2020. Penambahan Kulit Ari Biji Kedelai Hasil Fermentasi Menggunakan EM-4 Dalam Formulasi Ransum Pellet Broiler Terhadap Fraksi Serat. Agrisaintifika, Jurnal Ilmu-Ilmu Pertanian, Vol. 4, No. 2.

Martins, E. H., Vilela, A. P., Mendes, R. F., Mendes, L. M., Vaz, L. E. V. dS. B., Junior, J. B. G. 2018. Soybean Waste In Particleboard Production, Agricultural Sciences, Vol. 42 No. 2, pp. 186-194.

Rachman, Taufiqur. 2013. Penggunaan Metode Work Sampling Untuk Menghitung Waktu Baku Dan Kapasitas Produksi Karungan Soap Chip Di PT. SA. Jurnal Inovisi, Vol. 9, No. 1, pp. 48-60.

Rozikin, M. Z. Rozikin, Umar M. 2018. Rancang Bangun Mesin Pengupas Kulit Ari Kedelai Dengan Kapasitas $180 \mathrm{~kg} /$ Jam Untuk Industri Tempe. Mechonversio: Mecanical Engineering Journal, Vol. 1, No. 1, pp. 23-27.

Setiono, Yoga, Tarmukan, Putri, R. I. 2018. Pengaturan Kecepatan Motor DC pada Pengupas Kulit Kedelai Menggunakan Kontroler PID. Jurnal Elkolind, Vol. 5, No. 1, pp. 37-41.

Suhendra, Setiawan, Budi. 2012. Model Efisiensi Mesin Pengupas dan Pembelah Biji Kedelai Tipe Piringan Menggunakan Program Powersim. POSITRON Berkala Ilmiah Fisika, Vol. 2, No. 2, pp. 25-32.

Tarigan, Miska Irani. 2015. Pengukuran Standar Waktu Kerja Untuk Menentukan Jumlah Tenaga Kerja Optimal, WAHANA INOVASI, Vol. 4, No.1, pp. 26-35. 